\title{
Evaluation of updated nitric acid chemistry on ozone precursors and radiative effects
}

\author{
K. M. Seltzer ${ }^{1}$, W. Vizuete $^{2}$, and B. H. Henderson ${ }^{1}$ \\ ${ }^{1}$ Department of Environmental Engineering Sciences, University of Florida, Gainesville, FL, USA \\ ${ }^{2}$ Department of Environmental Science and Engineering, University of North Carolina, Chapel Hill, NC, USA \\ Correspondence to: K. M. Seltzer (karlseltzer@gmail.com) and B. H. Henderson (barronh@ufl.edu)
}

Received: 18 December 2014 - Published in Atmos. Chem. Phys. Discuss.: 3 February 2015

Revised: 15 April 2015 - Accepted: 11 May 2015 - Published: 29 May 2015

\begin{abstract}
This study shows that revising the reaction rate of $\mathrm{NO}_{2}+\mathrm{HO}^{\bullet} \rightarrow \mathrm{HNO}_{3}$ improves simulated nitrogen partitioning and changes the simulated radiative effects of several short-lived climate forcers (SLCF). Both laboratory and field study analyses have found that the reaction rate should be reduced by $13-30 \%$ from current recommendations. We evaluate the GEOS-Chem model over North America with and without the recommended update using observations from the Intercontinental Chemical Transport Experiment North America (INTEX-NA) Phase A campaign. Revising the $\mathrm{NO}_{2}+\mathrm{HO}^{\circ} \rightarrow \mathrm{HNO}_{3}$ rate coefficient improves model performance of oxidized nitrogen partitioning by increasing $\mathrm{NO}_{x}$ concentrations in the upper troposphere and decreasing $\mathrm{HNO}_{3}$ throughout the troposphere. The increase in $\mathrm{NO}_{x}$ concentrations has a corresponding global increase in $\mathrm{O}_{3}$ concentrations and local increases in sulfate aerosols, causing a perturbation in simulated radiative effects. These findings demonstrate the positive influence the mechanism update has on the partitioning of oxidized nitrogen species, the benefits it provides when compared to aircraft observations, and the simulated radiative effects that the reduction induces.
\end{abstract}

\section{Introduction}

Global chemical transport models (GCTMs) are excellent tools for exploring our scientific understanding. They are used to estimate concentrations fields, develop source-sink budgets for compounds, source-receptor relationships, infer emission inventories, and estimate the impact of emission reduction strategies (e.g., Jaeglé et al., 2003; Fusco and Logan, 2003; West et al., 2006; Chen et al., 2009; Millet et al.,
2010; West et al., 2009; Kopacz et al., 2010). The benefit of GCTMs to their regional counterparts is the scale that decreases sensitivity to boundary conditions (Jacobson, 2005). When new information on a process emerges in the literature, the GCTM must be evaluated in the context of that update. In addition, an understanding into how this update would have influenced conclusions from previous studies must be considered.

GCTMs are often used to predict ozone and aerosol concentrations that are products of photochemical oxidation. In the context of oxidation, the chemical component of GCTMs (a.k.a. chemical mechanism) indirectly influences all the other processes. Chemical transformation directly changes the chemical availability of compounds and the physical properties of compound families. For instance, Reaction (R1) decreases the photochemical availability of a hydroxyl radical $\left(\mathrm{HO}^{*}\right)$ and nitrogen oxides $\left(\mathrm{NO}_{x}=\mathrm{NO}+\mathrm{NO}_{2}\right)$. Reaction (R1) also increases the solubility of oxidized nitrogen since the Henry's Law coefficient for $\mathrm{HNO}_{3}(2.1 \times$ $10^{5} \mathrm{Matm}^{-1}$ at $\left.298 \mathrm{~K}\right)$ is 7 orders of magnitude greater than that of $\mathrm{NO}_{2}\left(10^{-2} \mathrm{Matm}^{-1}\right.$ at $\left.298 \mathrm{~K}\right)$. Uncertainty in Reaction (R1) would, therefore, affect the lifetime of $\mathrm{NO}_{x}$ emissions and the lifetime of $\mathrm{NO}_{y}$ as a $\mathrm{NO}_{x}$ reservoir. This is important for other molecules, such as ozone, since ozone production is limited, on average, by $\mathrm{NO}_{x}$ availability (Sillman et al., 1990; McKeen et al., 1991; Chameides et al., 1992; Jacob et al., 1993; Jaeglé et al., 1998a).

$\mathrm{NO}_{2}+\mathrm{HO}^{\bullet} \rightarrow \mathrm{HNO}_{3}$

Reaction (R1) is widely recognized as a key reaction in atmospheric oxidation (e.g., Seinfeld, 1989; Donahue, 2011), but has not been well constrained. Despite its known influence and importance, Reaction (R1) has proven difficult to 
measure at temperatures and pressures in the troposphere (Donahue, 2011). In a recent study, Mollner et al. (2010) employed state-of-the-science techniques to accurately measure the reaction rate at standard temperature and pressure ( $T=298 \mathrm{~K}$ and $P=1 \mathrm{~atm})$. In a subsequent study, Henderson et al. (2012) constrained the rate of Reaction (R1) using aircraft measurements from the upper troposphere $(T=$ $240 \mathrm{~K}$ and $P=0.29 \mathrm{~atm})$. Both of these studies recommend significant downward revisions, and the rate recommended in the upper troposphere suggests an update to the temperature sensitivity (Henderson et al., 2012).

As will be demonstrated in this study, updates to the rate of Reaction (R1) have the potential to change $\mathrm{NO}_{x}$, radical, and ozone concentrations. As well, since tropospheric ozone is a short-lived climate forcer (SLCF), changes in the simulated radiative flux are expected. This study implements the mechanism update in the GEOS-Chem chemical transport model and evaluates the impacts related to oxidized nitrogen partitioning. In addition to the effects on oxidized nitrogen partitioning and ozone precursors, the study also utilizes an offline radiative transfer model to evaluate the simulated instantaneous radiative forcing that this mechanism update produces. We hypothesize that the increased $\mathrm{NO}_{x}$ lifetime will increase $\mathrm{NO}_{x}$ concentrations, decrease $\mathrm{HNO}_{3}$ concentrations, reduce the ratio of $\mathrm{HO}^{\bullet}$ to $\mathrm{HO}^{\bullet}$ concentrations, and lead to localized positive radiative effects where ozone increases occur.

\section{Methods}

\subsection{Model description}

We simulate the Intercontinental Chemical Transport Experiment - North America (INTEX-NA) Phase A (INTEXA) time period (July-August 2004) using the GEOS-Chem global chemical transport model (version 9-01-02; Bey et al., 2001). The GEOS-Chem model explicitly simulates tracer species advection, diffusion, deposition, gas-phase reactions, and equilibrium partitioning of gasses and aerosols. This is accomplished by using inputs for meteorology, emissions, and chemistry. We configured GEOS-Chem to simulate 1 July to 30 August, with chemical concentrations produced at a horizontal resolution of $2^{\circ} \times 2.5^{\circ}$ and 47 vertical levels. We evaluated levels 1 through 32 , which range in resolution from $120 \mathrm{~m}$ near the surface to $1000 \mathrm{~m}$ at the top of the model. The simulated time frame covers the period observed by the National Aeronautics and Space Administration (NASA) aircraft (DC-8). While we have simulated global fields, the model evaluation covers the Northern Hemisphere, primarily over North America (see Fig. 1). The meteorological inputs are produced by the NASA Global Modeling and Assimilation Office (GMAO) and assimilate observations from the Goddard Earth Observing System version 5 (GEOS-5). The GEOS-5 system is the latest version and has observations starting on 1 January 2004. The model was configured to use cloud convection with a 15 min time step and planetary boundary mixing with the non-local option. The emissions include biomass (van der Werf et al., 2006), biogenic (Guenther et al., 2006), lightning (Ott et al., 2010), and anthropogenic emissions (described below).

Anthropogenic emissions of $\mathrm{NO}_{x}, \mathrm{CO}$, and $\mathrm{SO}_{2}$ are included at both a global and regional scale. At the regional scale, anthropogenic emissions of $\mathrm{NO}_{x}, \mathrm{CO}$, and $\mathrm{SO}_{2}$ are specifically provided for the United States of America, Europe, Mexico, and Southeast Asia. The United States emissions are derived from the EPA's National Emission Inventory (NEI) for the year 2005 and supplemented by the biofuel emission inventory from 1999. In contrast to the 1999 NEI, the mobile $\mathrm{NO}_{x}$ emissions from the 2005 NEI have compared well to fuel use estimates (Parrish, 2006; Dallmann and Harley, 2010). The European emissions are provided by the Co-operative Programme for Monitoring and Evaluation of the Long-range Transmission of Air Pollutants in Europe (EMEP) inventory for Europe in 2000 by Vestreng and Klein (2002). The Mexico emissions are derived from the 1999 Big Bend Regional Aerosol and Visibility Observational (BRAVO) emissions inventory for Mexico (Kuhns et al., 2003). Asia emissions are derived from Streets et al. (2003, 2006). For the rest of the world, emissions are derived from the Emission Database for Global Atmospheric Research (EDGAR) fossil fuel inventory and scaled from the year 2000 (Olivier et al., 2002).

\subsection{Chemistry updates}

In this study, we compare simulations with standard chemistry (base case) and revised chemistry $\left(\mathrm{HNO}_{3}\right.$ case). The reaction rate of $\mathrm{NO}_{2}+\mathrm{HO}^{\bullet}$ is decreased to account for emerging literature recommending a downward revision (Mollner et al., 2010; Henderson et al., 2012). Mollner et al. (2010) recommend a $13 \%$ decrease to the rate recommended by Sander et al. (2011), which is lower than that recommended by Atkinson et al. (2004). Donahue (2011) commended the recent work by Mollner et al. (2010), but asserted that there is remaining uncertainty. Henderson et al. (2012) also reevaluated the rate constant using Bayesian inference and measurements from the upper troposphere. The evaluation in the upper troposphere complements the Mollner et al. (2010) study with information at temperatures from 230 to $250 \mathrm{~K}$. Henderson et al. (2012) concluded that the temperature sensitivity is currently overestimated and should be revised according to Eqs. (1) and (2). As such, updates to GEOS-Chem in the $\mathrm{HNO}_{3}$ case are as follows:

$$
\begin{aligned}
k_{0} & =1.49 \times 10^{-30}\left(\frac{T}{300}\right)^{-1.8}, \\
k_{\infty} & =2.58 \times 10^{-11} .
\end{aligned}
$$




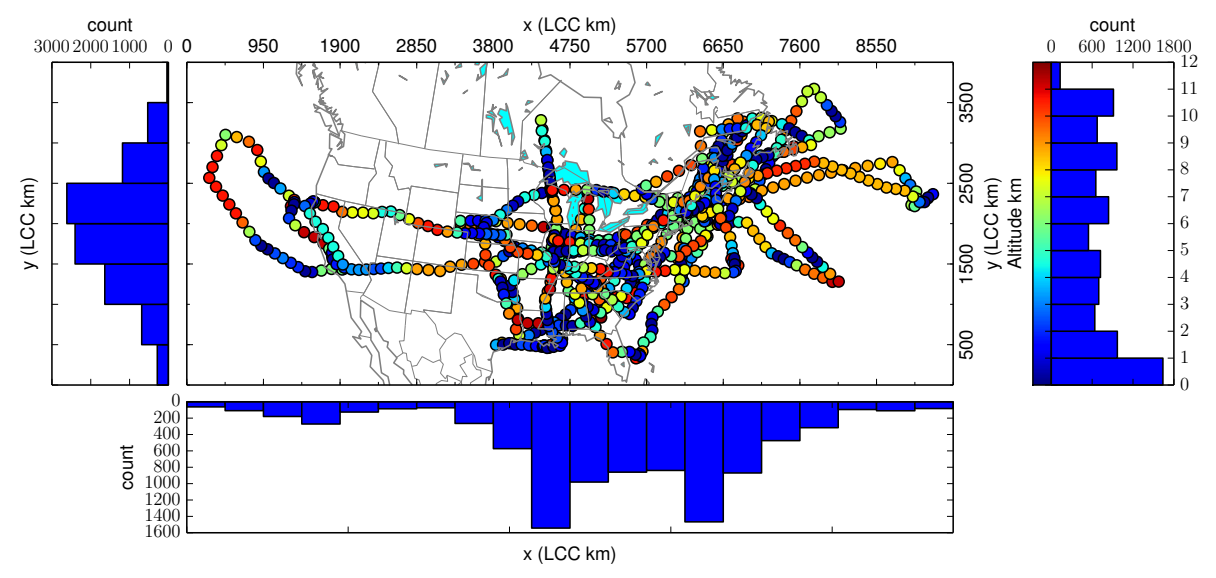

Figure 1. Sample locations (dots) from the INTEX-A campaign with altitude shown in color with histograms for latitude and longitude. The dots show every tenth sample, but the histograms use all samples.

\subsection{Observation description}

In this study, we evaluate the model using aircraft observations from the INTEX-A campaign. The INTEX-A campaign collected observations from $90 \mathrm{~m}$ to $11.9 \mathrm{~km}$ covering North America (Fig. 1). The suite of measurements from this campaign included inorganic species $\left(\mathrm{NO}, \mathrm{NO}_{2}, \mathrm{PAN}, \mathrm{HNO}_{4}\right.$, $\mathrm{HNO}_{3}, \mathrm{O}_{3}, \mathrm{H}_{2} \mathrm{O}_{2}$, and $\left.\mathrm{CO}\right)$ and organic species $\left(\mathrm{CH}_{2} \mathrm{O}\right.$, $\mathrm{CH}_{3} \mathrm{CHO}$, and $\mathrm{CH}_{3} \mathrm{C}(\mathrm{O}) \mathrm{CH}_{3}$ ). As with other studies (e.g., Hudman et al., 2007), the observations are filtered to exclude stratospheric intrusion, biomass burning, wildfires, and fresh pollution plumes. These events are excluded because the model is not designed to capture the variability of extreme events, or events on a horizontal scale smaller than the model resolution. First, stratospheric intrusion is identified when the ratio of $\mathrm{O}_{3}$ to $\mathrm{CO}$ is greater than 1.25. Biomass burning is identified by concentrations of hydrogen cyanide and acetonitrile greater than 500 and $225 \mathrm{ppt}$, respectively. Fresh pollution plumes are identified where $\mathrm{NO}_{x}$ was more than $40 \%$ of the total oxidized nitrogen $\left(\mathrm{NO}_{y} \equiv \mathrm{NO}_{x}+\mathrm{PAN}+\mathrm{HNO}_{3}\right)$, or if $\mathrm{NO}_{y}$ is not available, when $\mathrm{NO}_{2}>400$ ppt and below $3 \mathrm{~km}$.

For each measurement, an estimation or calculation of the uncertainty in the measurement technique was carried out. Depending on the measurement, the uncertainty was either provided on a per-sample basis or for the whole data set. Absolute uncertainty is provided on a per-sample basis, while relative uncertainty is provided for the data set. Relative uncertainty $(1 \sigma)$ was provided for $\mathrm{O}_{3}( \pm 5 \%), \mathrm{HO}^{\bullet}( \pm 15 \%)$, $\mathrm{HO}_{2}^{*}( \pm 15 \%)$, PAN $( \pm 15 \%)$, and $\mathrm{NO}_{2}( \pm 5 \%)$. For $\mathrm{HNO}_{3}$ (measured by P. Wennberg at the California Institute of Technology), uncertainty was provided as a column-wise absolute uncertainty that combines calibration, water correction, and background signal. The uncertainty was propagated from the $0.5 \mathrm{~s}$ timescale to the $1 \mathrm{~min}$ timescale through linear propagation. The $\mathrm{HNO}_{3}$ relative error simple average is $20 \%$, me- dian is $12 \%, 75$ th percentile is $19 \%$, and the concentration weighed average is $11 \%$.

The $\mathrm{NO}_{2}$ measurement has a known interference at low temperatures (Browne et al., 2011). At low ambient temperatures, pernitric acid $\left(\mathrm{HNO}_{4}\right)$ and methyl peroxy nitrate $\left(\mathrm{CH}_{3} \mathrm{O}_{2} \mathrm{NO}_{2} ; \mathrm{MPN}\right)$ dissociate in the inlet tube, adding molecules of $\mathrm{NO}_{2}$ to the measurement. When temperatures are above $255 \mathrm{~K}$, the interference is less than $5 \%$ and within stated uncertainty limits (Browne et al., 2011). However, when temperatures are below $255 \mathrm{~K}$, such as in the upper troposphere, the interference can be more than $15 \%$. For temperatures below $255 \mathrm{~K}$, we use a chemical box model (Henderson et al., 2012) to estimate the concentration of MPN and reduce the $\mathrm{NO}_{2}$ measurement accordingly. This chemical box model was validated with a modified version of GEOS-Chem that included MPN (not shown). Post-analysis of MPN suggests that the difference between the two models was less than a factor of 2. Box-model median MPN concentrations were $14 \mathrm{ppt}$ at $8 \mathrm{~km}$ and $17 \mathrm{ppt}$ at $10 \mathrm{~km}$. The modified GEOS-Chem median MPN concentrations were $15 \mathrm{ppt}$ from 8 to $9 \mathrm{~km}$ and $34 \mathrm{ppt}$ from 9 to $10 \mathrm{~km}$. Above $10 \mathrm{~km}$, the uncertainty in our box-model MPN predictions increase, which leads us to evaluate the mechanism update only below $10 \mathrm{~km}$. Although there are differences between the two models below $10 \mathrm{~km}$, they are insufficient in magnitude to alter our conclusions. In addition to individual measurements, this analysis focuses on species groups and algebraic combinations of measurements. The two most notable species groups are $\mathrm{NO}_{x}\left(\mathrm{NO}+\mathrm{NO}_{2}\right)$ and $\mathrm{NO}_{y}\left(\mathrm{NO}_{x}+\mathrm{PAN}+\mathrm{HNO}_{3}\right)$ and their uncertainty is simply the root of the summed squared error for each group.

For nitric oxide (NO), the direct measurement is not sensitive at the concentrations studied here. Nitric oxide was measured by chemiluminescence with a $50 \mathrm{ppt}$ lower limit of detection, which is too high to characterize the middle free troposphere (e.g., Bertram et al., 2007; Singh et al., 2007). As a 
Table 1. Measurement descriptive statistics (mean: $\bar{X}$; percentiles: 5, 50, 90\%), average relative uncertainty as a percent $\overline{\left(\frac{\sigma_{x}}{X}\right)} \%$, and absolute uncertainty in measurement units.

\begin{tabular}{lrrrrrrr}
\hline Measured (unit) & $N$ & $\bar{X}$ & $5 \%$ & $50 \%$ & $95 \%$ & $\overline{\left(\frac{\sigma_{x}}{X}\right)} \%$ & $\bar{\sigma}$ \\
\hline $\mathrm{NO}$ & 3745 & 95.1 & 4.9 & 30.1 & 361.9 & 7.3 & 6.9 \\
$\mathrm{NO} 2$ & 3995 & 94.9 & 7.8 & 39.8 & 335.4 & 5.0 & 4.7 \\
$\mathrm{HNO} 4$ & 2399 & 37.5 & 1.5 & 24.2 & 111.4 & 23.0 & 8.6 \\
$\mathrm{PAN}$ & 3046 & 268.9 & 13.0 & 225.8 & 658.4 & 15.0 & 40.3 \\
$\mathrm{HNO} 3$ & 2423 & 420.6 & 59.8 & 313.2 & 1109.8 & 21.0 & 51.1 \\
$\mathrm{NO}_{x}$ & 3745 & 182.1 & 14.3 & 77.4 & 621.7 & 4.7 & 9.0 \\
$\mathrm{NO}_{z}=\mathrm{PAN}_{+} \mathrm{HNO}_{3}$ & 1818 & 680.2 & 165.7 & 569.6 & 1527.8 & 12.2 & 68.3 \\
$\mathrm{NO}_{y}=\mathrm{NO}_{x}+\mathrm{PAN}_{+} \mathrm{HNO}_{3}$ & 1743 & 819.0 & 208.4 & 668.4 & 1919.1 & 9.9 & 68.3 \\
\hline
\end{tabular}

result, we calculate steady-state $\mathrm{NO}$ as described in Eq. (3), where $j$ is the photolysis rate, $T$ is the temperature, and "[]" denote concentrations. The uncertainty in the derived $\mathrm{NO}$ value is propagated from $\mathrm{NO}_{2}, \mathrm{O}_{3}$, and $\mathrm{HO}_{2}$, with the assumption that temperatures and reaction rates are precisely known.

$$
[\mathrm{NO}]_{s s}=\frac{j\left[\mathrm{NO}_{2}\right]}{3.3 \times 10^{-12} \times \exp \left(\frac{270}{T}\right)\left[\mathrm{HO}_{2}\right]+3.0 \times 10^{-12} \times \exp \left(\frac{-1500}{T}\right)\left[\mathrm{O}_{3}\right]}
$$

Descriptive statistics and uncertainties for the INTEX-A measurements are characterized in Table 1 . The table summarizes uncertainty evaluated for the whole data set, but the uncertainty at each altitude varies. For each measurement, Table 1 shows the number of valid measurements, mean $(\bar{X})$, percentiles $(5,50$, and $75 \%)$, and mean uncertainties (relative $\overline{\left(\frac{\sigma_{x}}{X}\right)} \%$; absolute $\bar{\sigma}$ in measurement units).

\subsection{Method of model evaluation}

The simulations spatially average concentration over a $48000 \mathrm{~km}^{2}$ area, reducing the variance of chemical concentrations. While the observations also spatially average concentrations, their line segments only range from 4 to $17 \mathrm{~km}$. Based on these differences alone, we expect the observed and simulated population data sets to each have their own mean and variance for each chemical species. For lognormally distributed species $\left(\mathrm{NO}_{x}, \mathrm{HNO}_{3}\right)$, the means cannot be compared because the variances are expected to be different. In this case, the species can be log transformed to reduce the bias of the mean, but the variances of the observations and model are still different. This difference precludes certain statistical evaluation techniques, such as the Student's $t$ test, from being used in this evaluation.

To alleviate this problem, a variant of the Student's $t$ test, called the Welch's $t$ test, is used. The Welch's $t$ test (hereafter $t$ test) is a variant of the Student's $t$ test that calculates the combined variance using the Welch-Satterthwaite equation (Welch, 1947). The $t$ test estimates the probability that the measured and modeled mean could be obtained given re- peated sampling, with the assumption that the true means are the same. This type of test does not inherently account for potential bias in the measurements, but can be used as part of a framework that does.

The true bias of a measurement cannot be known until it is compared to a superior method under similar circumstances. There is, currently, insufficient data to fully characterize all the biases of measurements made during the INTEXA campaign. For some measurements, however, multiple techniques produce different answers or subsequent analysis demonstrates a bias. In order to account for measurement uncertainty, we use a method referred to as the two one-sided $t$ tests (TOST) (Schuirmann, 1987). Using TOST, we can test whether the model predictions are within measurement uncertainty by rejecting one of two null hypotheses. The first null hypothesis is that the simulated mean is greater than the observations adjusted to their lower bound. The second null hypothesis is that the simulated mean is less than the observations adjusted to their upper bound. If we reject either hypothesis, we have rejected that the model mean is equivalent to the observation mean. This approach is equivalent to assuming a systematic bias equal to the uncertainty in the measurement. Using relative uncertainty, we formulate the null hypotheses $\left(H_{0,1}\right.$ and $H_{0,2}$; shown below) using products. For each measurement, the observed accuracy is based on an estimate, which can be found in the header of the observation files.

$$
\begin{aligned}
H_{0,1}: \mu_{\mathrm{mod}} & \geq \mu_{\mathrm{obs} \times(1-U)} \\
H_{0,2} \mu_{\mathrm{mod}} & \leq \mu_{\mathrm{obs} \times(1+U)}
\end{aligned}
$$

For each simulation, we evaluate the model in $1 \mathrm{~km}$ vertical bins. This method of evaluation was chosen since temperature, pressure, and transport have large variability throughout the vertical troposphere, and these variables play a strong role in the rate of Reaction (R1). In each vertical bin, we compare populations of observed and simulated chemical concentrations. By default, the plane flight sampling in GEOS-Chem outputs one prediction for each observation. The model's larger spatial and temporal averaging, however, means that a model grid cell can be paired with more than one 
observation. In these occurrences, model predictions were not double counted. Following this process, two data sets (observations and predictions) existed for each altitude bin that combined to represent a sample of the atmosphere.

We evaluate the model by using the $t$ test for species and species groups to examine their bias. This evaluation will include $\mathrm{NO}_{x}$ and the family of compounds involved in its cycling, which largely drives photochemical ozone production. As such, we evaluate $\mathrm{NO}_{x}$ and its products by defining $\mathrm{NO}_{y}$ as the sum of $\mathrm{NO}_{x}, \mathrm{PAN}$, and $\mathrm{HNO}_{3}$ $\left(\frac{\mathrm{NO}_{x}+\mathrm{PAN}^{2}+\mathrm{HNO}_{3}}{\mathrm{NO}_{x}+\mathrm{PAN}+\mathrm{HNO}_{3}+\mathrm{HNO}_{4}+\mathrm{RNO}_{3}}>88 \%\right.$ for $90 \%$ of all samples). Since there is a bias in $\mathrm{NO}_{y}$ (see Results), the evaluation of $\mathrm{NO}_{y}$ components is performed on a normalized basis.

\subsection{Radiative effects}

Changes in nitric acid formation affect the concentrations of various SLCF. These forcers have the capacity to affect localized climate and change the radiative budget. For this study, these forcings are largely driven by changes in tropospheric ozone concentrations. To assess the radiative effects of changing the nitric acid reaction rate, the Parallel Offline Radiative Transfer (PORT) model was used (Conley et al., 2013). This stand-alone model was developed at the National Center for Atmospheric Research (NCAR) and isolates the radiation code from the Community Atmosphere Model (CAM). The model calculated the direct instantaneous radiative forcing due to the nitric acid kinetic update, strictly as it relates to changes in atmospheric composition simulated by GEOS-Chem.

Input to PORT was compiled using output from the GEOS-Chem simulations. An instantaneous tracer time series output was created for every 73rd time step, which resulted in output generated every $2190 \mathrm{~min}$. This output schedule enabled a balance of sampling all seasons, day and night occurrences, output files sizes, and overall computational strain. Conley et al. (2013) found such a sub-sampling routine to have less than a $0.1 \%$ relative error in the radiative flux when compared to a PORT simulation using every time sample. The radiative flux is defined as the net change in net downward solar and terrestrial (combined) radiation. Initial analysis of the GEOS-Chem output indicated that the main driver of instantaneous radiative forcing was tropospheric ozone and, to a lesser extent, sulfate aerosols. The instantaneous radiative forcing simulation was carried on for a full year to allow for a calculation of a global annual average change in instantaneous radiative forcing. While the GEOS-Chem evaluation was limited to the time period of the INTEX-A campaign, the radiative effects portion of this evaluation had no such limitations.

\section{Results}

\subsection{Evaluation of updated nitric acid chemistry on atmospheric composition}

In this section, the base case and $\mathrm{HNO}_{3}$ case models are compared to the INTEX-A observations, with a focus on $\mathrm{NO}_{y}$ and the partitioning of $\mathrm{NO}_{y}$ species. Each component is evaluated in $1 \mathrm{~km}$ vertical bins from the surface $(0 \mathrm{~km})$ to $10 \mathrm{~km}$. Due to the high bias of total oxidized nitrogen $\left(\mathrm{NO}_{y}=\mathrm{NO}_{x}+\mathrm{PAN}+\mathrm{HNO}_{3}\right)$ throughout most of the troposphere (as evident in Fig. 2a), the remaining evaluation will feature a $\mathrm{NO}_{y}$ normalization.

Figure 2 shows the concentration of total oxidized nitrogen $\left(\mathrm{NO}_{y}\right)$ and the fractional amount of its components $\left(\mathrm{NO}_{x}\right.$, PAN, and $\mathrm{HNO}_{3}$ ). For each $1 \mathrm{~km}$ bin, Fig. 2 shows the mean (black dots), median (white lines), and $90 \%$ range (5-95\%) of the observed (grey bars) and simulated values (base: blue, $\mathrm{HNO}_{3}$ : red). The dots that represent the simulated means are black if the model mean is consistent with the observations (i.e., we cannot reject $H_{0,1}$ and $H_{0,2}$ ) and blank if the model mean is not statistically consistent with observations. Figure 2a shows that $\mathrm{NO}_{y}$ performance changes as a function of altitude. From 0 to $8 \mathrm{~km}$, both models feature statistically significant high biases of their mean values. As well, simulated $\mathrm{NO}_{y}$ is less concave than observed, especially in the midtroposphere, where observed values are at their minimum.

Between 8 and $10 \mathrm{~km}$, the updated chemistry improves the partitioning predictions of $\mathrm{NO}_{x}, \mathrm{HNO}_{3}$, and PAN. For $\mathrm{NO}_{x}$, both cases are low biased from 8 to $10 \mathrm{~km}$; however, the $\mathrm{HNO}_{3}$ case shows improvements. For $\mathrm{HNO}_{3}$, both the base and $\mathrm{HNO}_{3}$ cases are high biased from 8 to $10 \mathrm{~km}$, but once again, the $\mathrm{HNO}_{3}$ case shows improvements. In fact, the 8 to $9 \mathrm{~km}$ observed and simulated mean values no longer show statistically significant differences. For PAN, Fig. 2d shows more incremental improvements in the upper troposphere. On an overall basis, the $\mathrm{HNO}_{3}$ case provides slight improvements in model performance of $\mathrm{NO}_{y}$ partitioning in the upper troposphere.

When addressing nitrogen partitioning in the middle and lower troposphere, Fig. 2b shows that both models underpredict $\mathrm{NO}_{x}$ partitioning from 0 to $2 \mathrm{~km}$. However, when viewing Fig. $\mathrm{A} 1 \mathrm{~b}$, it is seen that predicted $\mathrm{NO}_{x}$ concentrations have high biases. Therefore, this partitioning bias is likely the result of high-biased total $\mathrm{NO}_{y}$ concentrations. Nonetheless, the $\mathrm{HNO}_{3}$ case decreases the simulated low bias for $\mathrm{NO}_{x}$ partitioning. The $\mathrm{HNO}_{3}$ case improves the predictions of $\mathrm{HNO}_{3}$ partitioning throughout most of the middle and lower troposphere, but significant improvements in predicted $\mathrm{NO}_{x}$ and $\mathrm{NO}_{y}$ concentrations are needed to help alleviate the overall bias. For PAN, Fig. $2 d$ shows that both scenarios predict high speciation at the surface and low speciation in the middle troposphere. However, throughout the middle troposphere, the $\mathrm{HNO}_{3}$ case increases the PAN normalized fraction, which improves model partitioning predictions. 


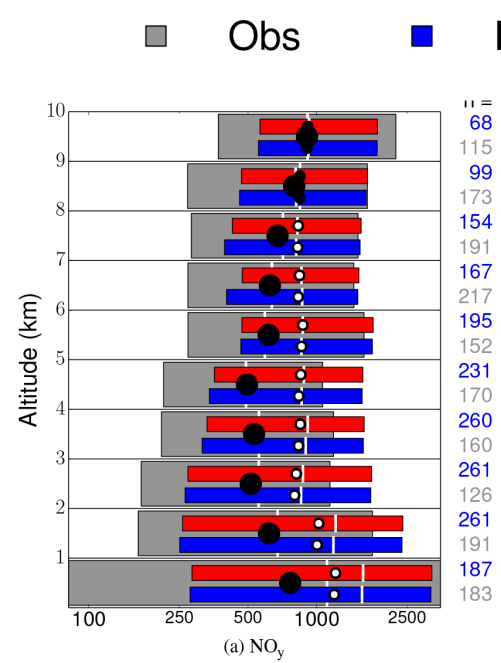

Base $\square \mathrm{HNO} 3$
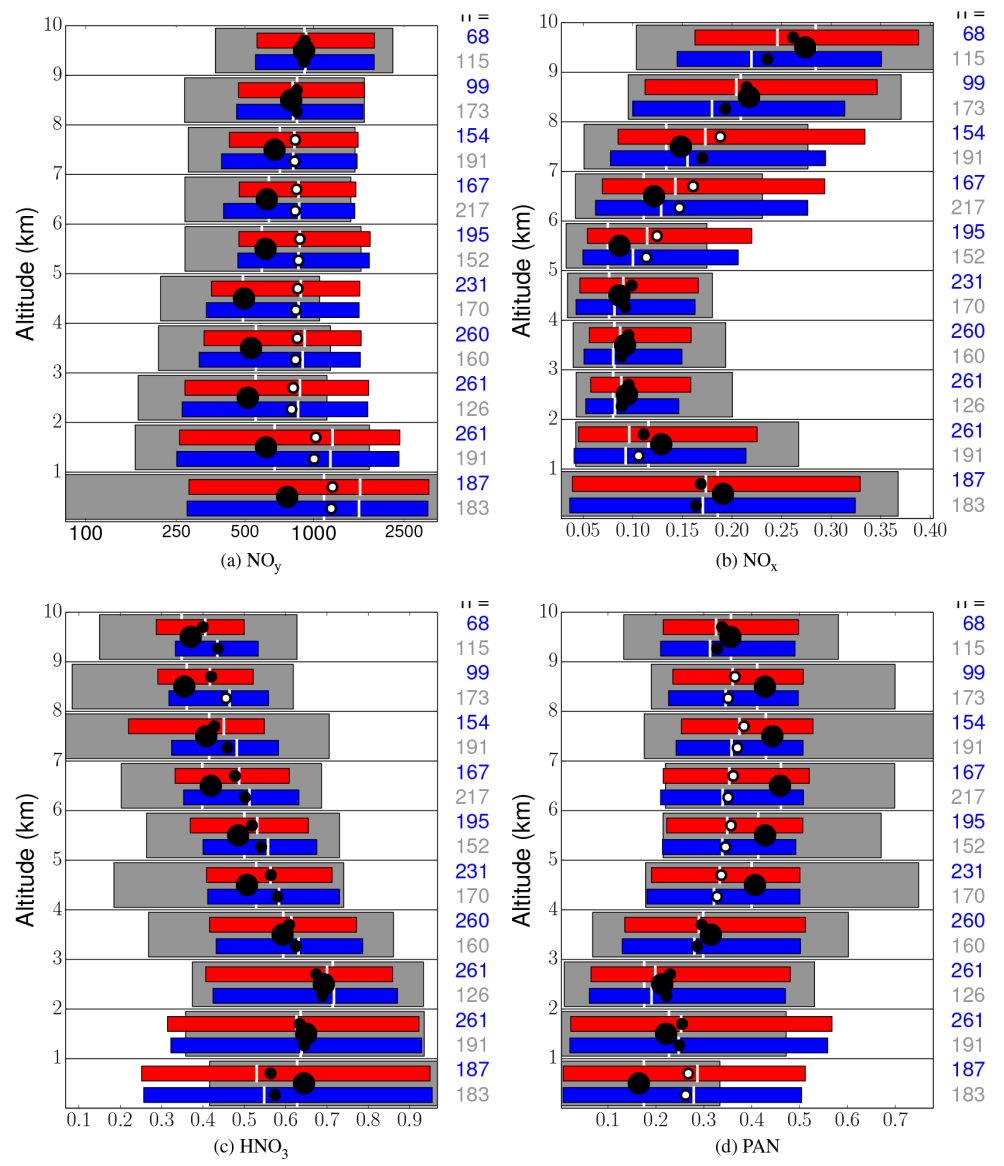

Figure 2. Model evaluation at ten $1 \mathrm{~km}$ vertical bins. Each panel shows the 5th to 95th percentile range (box), median (white line), and mean (circle) for observations (grey), the base case (blue), and the $\mathrm{HNO}_{3}$ case (red). When the mean circle for the predictions is filled in, the mean values between the observations and the predictions are not statistically different. The time period of these values matches the INTEX-A time period. The number of observations (black) and model points (blue) per $1 \mathrm{~km}$ bin are detailed in the margin.

Using the updated chemistry also exacerbates an existing high bias of ozone (not shown). The base case ozone predictions are high biased throughout most of the troposphere and are likely due to over-predictions of $\mathrm{NO}_{y}$ and $\mathrm{NO}_{x}$. This may be the result of lightning emissions, which are highly uncertain and will be discussed later. Another important observation from Fig. 2 is that $\mathrm{NO}_{y}$ partitioning is altitude dependent. In the middle troposphere, $\mathrm{NO}_{x}$ concentrations and partitioning are biased high (both $\left[\mathrm{NO}_{x}\right]$ and $\mathrm{NO}_{x}: \mathrm{NO}_{y}$ ). In the middle and upper troposphere, $\mathrm{HNO}_{3}$ concentrations and partitioning are also biased high and likely a function of the similar high bias seen for $\mathrm{NO}_{x}$. However, PAN is biased high near the surface (both [PAN] and PAN : $\mathrm{NO}_{y}$ ), but generally consistent with observations on a concentration basis and low biased on a partitioning basis in the middle to upper troposphere.

\subsection{Radiative effects of updated chemistry}

The SLCF that experienced changes between the base and $\mathrm{HNO}_{3}$ case were ozone and sulfate. As such, these climate forcers were the main focus of this radiative effects analysis. The global annual average instantaneous radiative forcing at the surface and top of the model due to the updated nitric acid mechanism was 6.7 and $27.8 \mathrm{~mW} \mathrm{~m}^{-2}$, respectively. For PORT, the top of the model is $2.194 \mathrm{hPa}$. The increase in ozone concentrations caused an increase in radiative flux at the surface and the top of the model of 10.4 and $31.0 \mathrm{~mW} \mathrm{~m}^{-2}$, respectively. Similar to ozone, there was a net increase in sulfate aerosols, which occurred mainly in the lower troposphere and over landmasses. These increases resulted in a net decrease in instantaneous radiative forcing, driven by the reflectance of incoming solar radiation. The decreases were -3.4 and $-3.1 \mathrm{~mW} \mathrm{~m}^{-2}$ at the surface and top of the model, respectively. 



Figure 3. Annual averaged instantaneous radiative forcing, in $\mathrm{mW} \mathrm{m}^{-2}$, at the surface (top) and top of the model (middle) for ozone. Net downward atmospheric forcing is shown in the bottom plot for ozone. Unlike the chemical mechanism evaluation, this simulation spanned a full year to enable an annual averaged calculation.

Figures 3 and 4 corroborate that ozone was the stronger contributor to surface and top of model direct instantaneous radiative forcing, with more localized effects observed for sulfate. The range of the colorbars in the two respective figures are similar, allowing for a comparison of the magnitude and spatial differences between the two SLCF. In total, Fig. 3 displays the annual average instantaneous radiative forcing due to the changes in ozone from the updated mechanism at the surface, top of model, and the net atmospheric forcing. The net atmospheric forcing is defined as the top of the atmosphere radiative forcing minus the surface radiative forcing and has strong influences on regional precipitation (Shindell et al., 2012).

Figure 3 shows that there is a global increase in instantaneous radiative forcing due to the increases in ozone concentrations. In addition, the instantaneous radiative forcing sim-

Figure 4. Annual averaged instantaneous radiative forcing, in $\mathrm{mW} \mathrm{m}^{-2}$, at the surface (top) and top of model (middle) for sulfate aerosols. Net downward atmospheric forcing is shown in the bottom plot for sulfate aerosols. Unlike the chemical mechanism evaluation, this simulation spanned a full year to enable an annual averaged calculation.

ulations indicate that the maximum increases occur in the mid-latitudes. Figure 3 also shows that higher values of instantaneous radiative forcing occur at the top of model, when compared to the surface. This leads to a net increase in the atmospheric forcing, which is shown in the third panel of Fig. 3. The maximum of this value is above the Equator and tapers off towards either pole.

Figure 4 displays the annual average instantaneous radiative forcing due to the changes in sulfate from the updated mechanism at the surface, top of model, and the net atmospheric forcing. In contrast to Fig. 3 and the global increase in radiative flux associated with ozone, the simulated instantaneous radiative forcing associated with sulfate was localized. These areas were predominantly over land, with the heaviest changes above highly polluted areas, such as China 


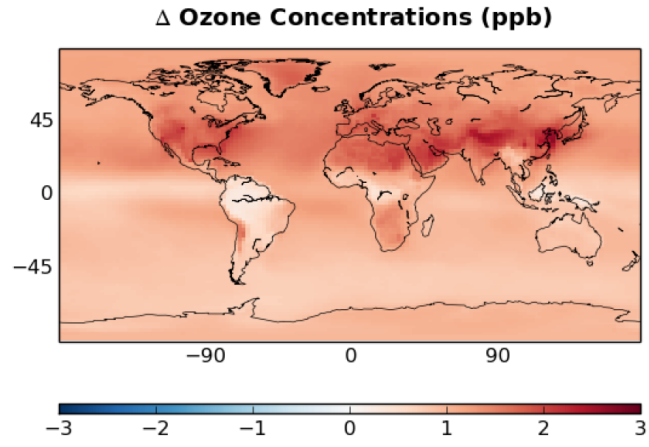

$\triangle$ HNO3 Concentrations (ppt)

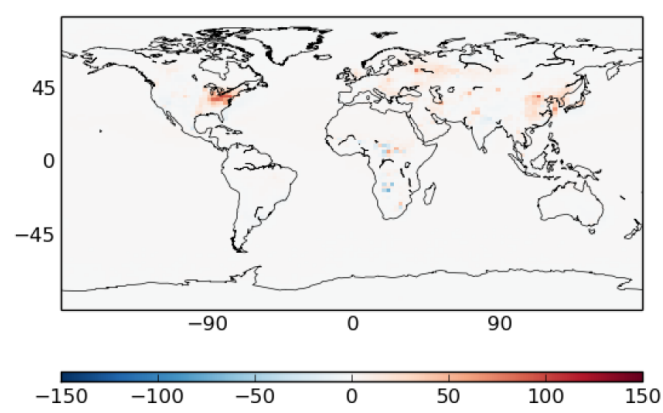

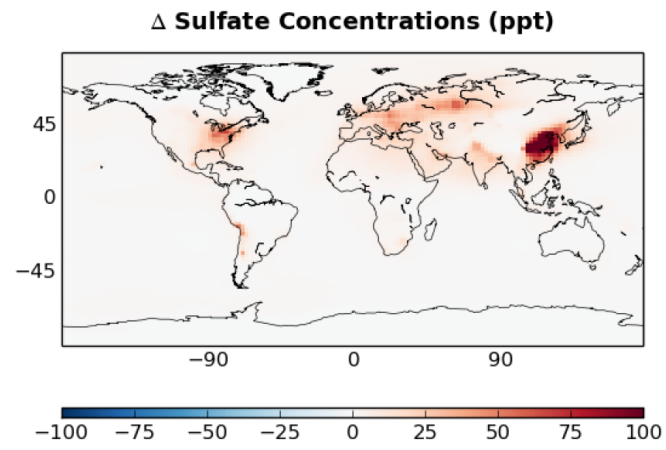

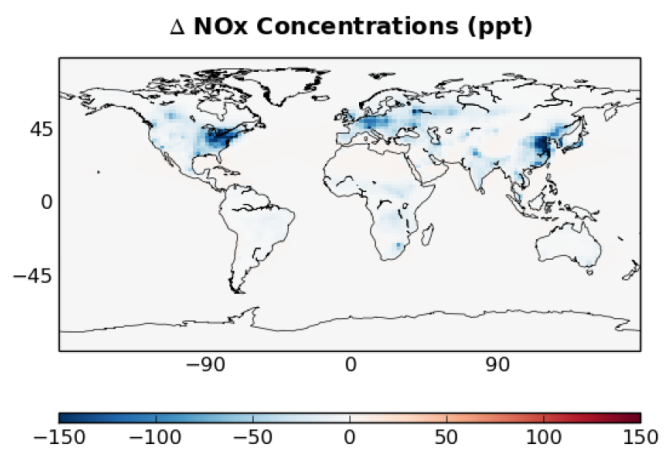

Figure 5. Difference in mean ozone, sulfate, nitric acid and $\mathrm{NO}_{x}$ mixing ratios mixing ratios between the $\mathrm{HNO}_{3}$ and base case simulations for the surface layer. The simulation period spanned an entire year.

and the Northeastern United States. Also in contrast to the instantaneous radiative forcing associated with ozone, the radiative effects associated with sulfate strictly resulted in decreases to the radiative flux.

\subsection{Spatial variations of short-lived climate forcers}

This section describes the spatial concentration changes of the SLCF studied in this analysis, as well as some of the species that play a role in their variations $\left(\mathrm{HNO}_{3}, \mathrm{NO}_{x}\right)$. In total, changes in their horizontal and vertical patterns, due to the revised mechanism, will be shown. Figures 5 and 6 show that the increases in ozone occurred globally, with maximum increases occurring in the upper mid-latitudes, spanning the entire vertical domain. Vertically, most of the ozone changes occurred in the free troposphere, above the planetary boundary layer. For sulfate, Fig. 5 indicates that the surficial changes were nearly all over landmasses that are traditionally locations of high pollution. However, when viewed in the vertical domain, Fig. 6 shows that the changes to sulfate concentrations were limited to areas near the surface and in the upper mid-latitudes.

Figure 5 shows that the localized concentration changes to $\mathrm{HNO}_{3}$ and $\mathrm{NO}_{x}$ in the surficial layer had an inverse relationship with one another, and occurred in the same localized regions as the concentration changes to sulfate. When reviewing Reaction (R1), this inverse relationship is expected. However, the decrease in the formation of nitric acid due to this mechanism update would lead to an expected increase in $\mathrm{NO}_{x}$, which is not shown in Fig. 5. When viewing Fig. 6, it is seen that this phenomenon is limited to the surface and quickly changes throughout the rest of the troposphere. This is likely due to an increase in heterogeneous nitrogen chemistry on the surface of the locally increased sulfate aerosols (Bell et al., 2005; Liao et al., 2004). Figure 6 shows that, once again, the concentration changes for $\mathrm{HNO}_{3}$ and $\mathrm{NO}_{x}$ are inversely related throughout the troposphere. It should also be noted that the strongest differences in $\mathrm{HNO}_{3}$ and $\mathrm{NO}_{x}$ concentrations occurred in the upper troposphere, where the updated chemistry plays a stronger role.

\section{Discussion on continued model bias}

While the updated chemistry helped improve the predictions of speciated $\mathrm{NO}_{y}$ at most levels of the atmosphere, several model biases are still observed. One such bias is the over-predictions of $\mathrm{NO}_{x}$ and $\mathrm{NO}_{y}$ in the middle troposphere. Sources of $\mathrm{NO}_{x}$ in these areas include convectively lofted anthropogenic $\mathrm{NO}_{x}$, lightning, transport from the stratosphere, and aircraft emissions (Jaeglé et al., 1998b; Hudman et al., 2007). In this study, the observations are filtered to exclude stratospheric intrusion and Allen et al. (2012) found that the impact of aircraft $\mathrm{NO}$ emissions on upper tropospheric $\mathrm{NO}_{x}$ during a flight path from the INTEX-A campaign were generally small. Though, it was stated that the impacts related 

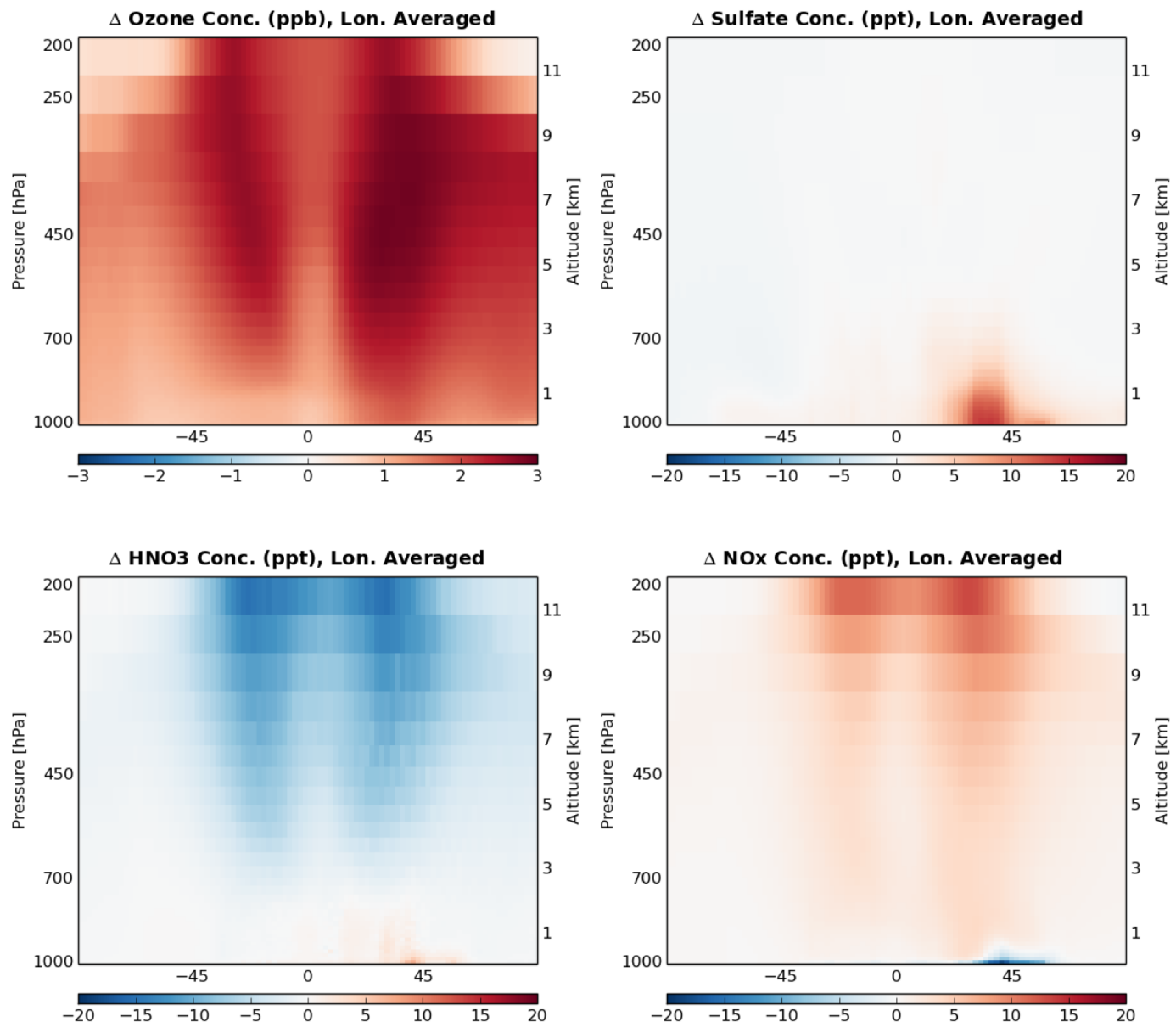

Figure 6. Vertical difference in mean nitric acid, $\mathrm{NO}_{x}$, ozone and sulfate mixing ratios between the $\mathrm{HNO}_{3}$ and base case simulations (longitudinally averaged values). The simulation period spanned an entire year.

to aircraft $\mathrm{NO}$ emissions are more evident in periods of low lightning $\mathrm{NO}_{x}\left(\mathrm{LNO}_{x}\right)$ emissions. This leaves either $\mathrm{LNO}_{x}$ or convectively lofted anthropogenic $\mathrm{NO}_{x}$ as the main drivers of this bias. Hudman et al. (2007) studied upper tropospheric $\mathrm{NO}_{x}$ during the INTEX-A campaign using GEOS-Chem and found that lightning was the dominant factor in upper tropospheric $\mathrm{NO}_{x}$ bias. Though, the largest bias from their study was in regions of the upper troposphere above the domain used in this study and they were low biased. As well, their version of GEOS-Chem utilized an older vertical release profile of $\mathrm{LNO}_{x}$. Newer GEOS-Chem versions, such as the one used in this study, utilize the vertical release profiles developed by Ott et al. (2010). In these updated profiles, large portions of upper and lower tropospheric $\mathrm{LNO}_{x}$ fractions were moved to the middle troposphere. Figure 7 displays the vertical $\mathrm{LNO}_{x}$ emission profile for the subtropical regions used in GEOS-Chem (Ott), which is following convection, and two other vertical $\mathrm{LNO}_{x}$ emission profiles, which were used by Allen et al. (2012). While all $\mathrm{LNO}_{x}$ vertical profiles display low fractional emissions near the surface, which was one of the significant updates made in Ott et al. (2010), variations do exist in the middle troposphere. These areas happen to be locations where high bias of $\mathrm{NO}_{x}-\mathrm{NO}_{y}$ partitioning and $\mathrm{NO}_{x}$ concentrations mainly occur. It is hypothesized that a bi-modal lighting profile, similar to some of the observations by Ott et al. (2010) and used by Allen et al. (2012), which include a redistribution of some of the $\mathrm{NO}_{x}$ emissions from the middle troposphere to the upper troposphere, could improve the predictions. In addition to the improvements in $\mathrm{NO}_{x}$ predictions, this update could also improve $\mathrm{NO}_{y}$ concentrations and $\mathrm{HNO}_{3}$-PAN partitioning.

The simulated concentrations of PAN, which match observations relatively well in the middle and upper troposphere, as seen in Fig. A1d, are most likely tied to the low bias for acetaldehyde and high bias for $\mathrm{HO}^{\circ}$. The high-biased $\mathrm{HO}^{\circ}$ would preferentially remove fast reacting compounds, like acetaldehyde $\left(k_{\mathrm{HO}} \cdot=4.63 \times 10^{-12} \times \exp (350 / T)\right)$, compared to acetaldehyde's precursors, ethane $\left(k_{\mathrm{HO}} \cdot=7.6 \times\right.$ $\left.10^{-12} \times \exp (-1020 / T)\right)$ and ethanol $\left(k_{\mathrm{HO}} \cdot=3.15 \times 10^{-14}\right)$. This suggests, as did Millet et al. (2010), that there is not, in fact, a missing source of acetaldehyde. Instead, an imbalance caused by over-predicted sinks causes acetaldehyde 


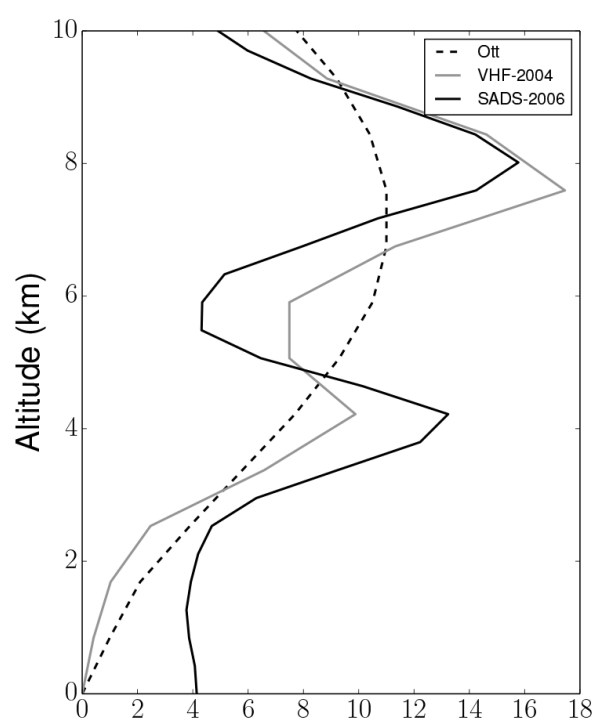

Figure 7. Vertical lightning emission profiles. The Ott $\mathrm{LNO}_{x}$ vertical emission profile is used by GEOS-Chem in the subtropical regions (Ott et al., 2010). The VHF-2004 and SADS-2006 $\mathrm{LNO}_{x}$ vertical emission profiles are alternative $\mathrm{LNO}_{x}$ emission profiles and were used in the study by Allen et al. (2012). The horizontal axis represents the fractional percentage of $\mathrm{LNO}_{x}$ emitted.

underpredictions, which lead to low $\mathrm{CH}_{3} \mathrm{C}(\mathrm{O}) \mathrm{OO}^{\bullet}$ radicals and reduced PAN formation. The updated chemistry used here exacerbates the $\mathrm{HO}^{*}$ bias and, in turn, typically lowers the model bias for PAN, which would not be as well simulated in circumstances with proper concentrations of $\mathrm{HO}^{\circ}$. More research is necessary to constrain this problem.

Similar to the changes in oxidized nitrogen concentrations, the change in simulated ozone concentrations is modest. The updated model increases the availability of $\mathrm{NO}_{x}$, which is generally the limiting species in tropospheric ozone production. Simulations using the updated chemical mechanism saw global increases of ozone throughout the troposphere, which increases the model bias. This further suggests that constraints on $\mathrm{NO}_{x}$ emissions are needed to improve modeled ozone concentrations.

\section{Conclusions}

Updates to the $\mathrm{NO}_{2}+\mathrm{HO}^{\bullet}$ reaction rate, as suggested by Mollner et al. (2010) and Henderson et al. (2012), were implemented in GEOS-Chem and the resulting model performance was evaluated using observations from the INTEXNA, Phase-A campaign. This evaluation considered total $\mathrm{NO}_{y}$ concentrations, $\mathrm{NO}_{y}$ partitioning, and the resulting direct instantaneous radiative forcing effects from this mechanism update. An initial comparison found that the base model had a high bias for $\mathrm{NO}_{y}$. As such, $\mathrm{NO}_{y}$ components $\left(\mathrm{NO}_{x}\right.$, $\mathrm{HNO}_{3}$, and PAN) were evaluated as fractional components to determine how the mechanism effects speciation. Overall, the updated chemistry improves oxidized nitrogen partitioning and decreased the termination of $\mathrm{NO}_{x}$ in the atmosphere through the formation of nitric acid.

In the upper troposphere, the updated chemistry improves modeled results for the partitioning of all $\mathrm{NO}_{y}$ components. In the middle troposphere, $\mathrm{HNO}_{3}$ and PAN also show improvements in predictions; however, the updated chemistry exacerbates a base model bias for $\mathrm{NO}_{x}$. Results in the lower troposphere show increased model bias for $\mathrm{HNO}_{3}$ and PAN. Therefore, additional work is recommended to understand the partitioning of $\mathrm{NO}_{x}$ in the middle troposphere and $\mathrm{HNO}_{3}$ and PAN near the surface.

A near-global increase in ozone concentrations and localized changes in sulfate concentrations also resulted from this update. These variations in short-lived climate forcers have an immediate impact on the amount of trapped energy in the atmosphere. Ozone concentration increases were a result of increased $\mathrm{NO}_{x}$ availability, whereas sulfate increases, which were spatially heterogeneous, are hypothesized to be a result of changes in atmospheric oxidation capacity. Variations in the atmospheric oxidation capacity result from a decrease in the formation of $\mathrm{HNO}_{3}$, which requires $\mathrm{NO}_{2}$ and $\mathrm{HO}$. This increase in $\mathrm{HO}^{-}$enables an increase in the oxidation of $\mathrm{SO}_{2}$ to $\mathrm{SO}_{4}$. Sulfate generally increased over traditionally polluted areas, such as eastern China and the Northeastern United States. Corresponding decreases in $\mathrm{HNO}_{3}$ were simulated throughout the troposphere above these locations, which corroborates the hypothesis that the sulfate increases were likely a result to the changing atmospheric oxidation capacity.

The radiative effects due to the changes in ozone and sulfate concentrations were evaluated using an offline radiative transfer model. The annual average instantaneous radiative forcing was largely driven by the changes in ozone concentrations, with slight effects from sulfate aerosols. Overall, an annual average instantaneous radiative forcing of 6.7 and $27.8 \mathrm{~mW} \mathrm{~m}^{-2}$ was simulated for the surface and the top of model, respectively. The radiative effects from ozone were seen globally, with maximum variances in the mid-latitudes. In contrast, the radiative effects resulting from the changes in sulfate were generally limited to areas over landmasses.

To put these global annual average values into perspective, the Intergovernmental Panel on Climate Change (IPCC) Assessment Report 5 (AR5) estimated that the total radiative forcing since pre-industrial times due to ozone is $350 \mathrm{~mW} \mathrm{~m}^{-2}$. While the concentrations of tropospheric ozone have many determinants beyond the kinetic rate of nitric acid formation, the comparison of model predictions to published values of historical ozone forcing enables a comparative base line to analyze these results against. As well, additional radiative effects can be expected due to this mechanism update. In the tropics, where a net positive increase in atmospheric forcing is simulated, additional atmospheric responses and feedbacks are likely to occur. These feedbacks include changes in atmospheric moisture and cloud cover. 
Since the radiative transfer model used in this evaluation was offline, these calculations were not included and should be considered in future work.

Overall, this study demonstrates that updates to the nitric acid chemical mechanism generally improves oxidized nitrogen partitioning performance in GEOS-Chem throughout the troposphere. It should be noted, however, that this model evaluation is based on a model that is already high-biased for $\mathrm{NO}_{y}$ concentrations throughout a majority of the troposphere. As such, improvements to the global emission inventories could significantly help the overall modeled concentrations of total oxidized nitrogen. 


\section{Appendix A: Total oxidized nitrogen concentrations}

The main text shows total oxidized nitrogen partitioning (see Fig. 2), but not concentrations of component species $\mathrm{NO}_{x}$, $\mathrm{HNO}_{3}$, or PAN. Figure A1 provides concentration data to complement Fig. 2.

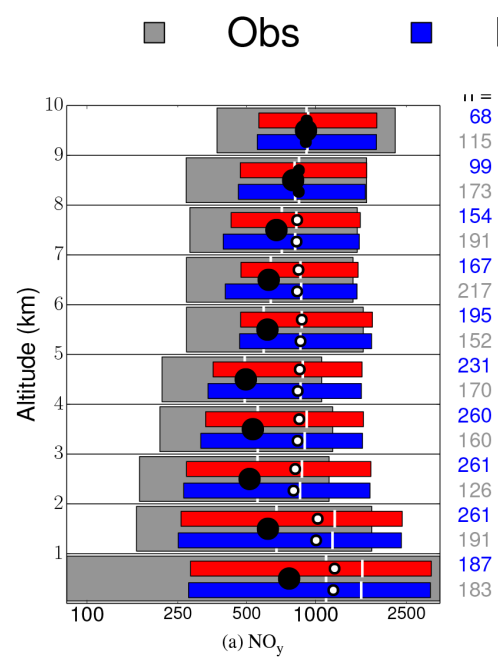

Base $\square \mathrm{HNO} 3$
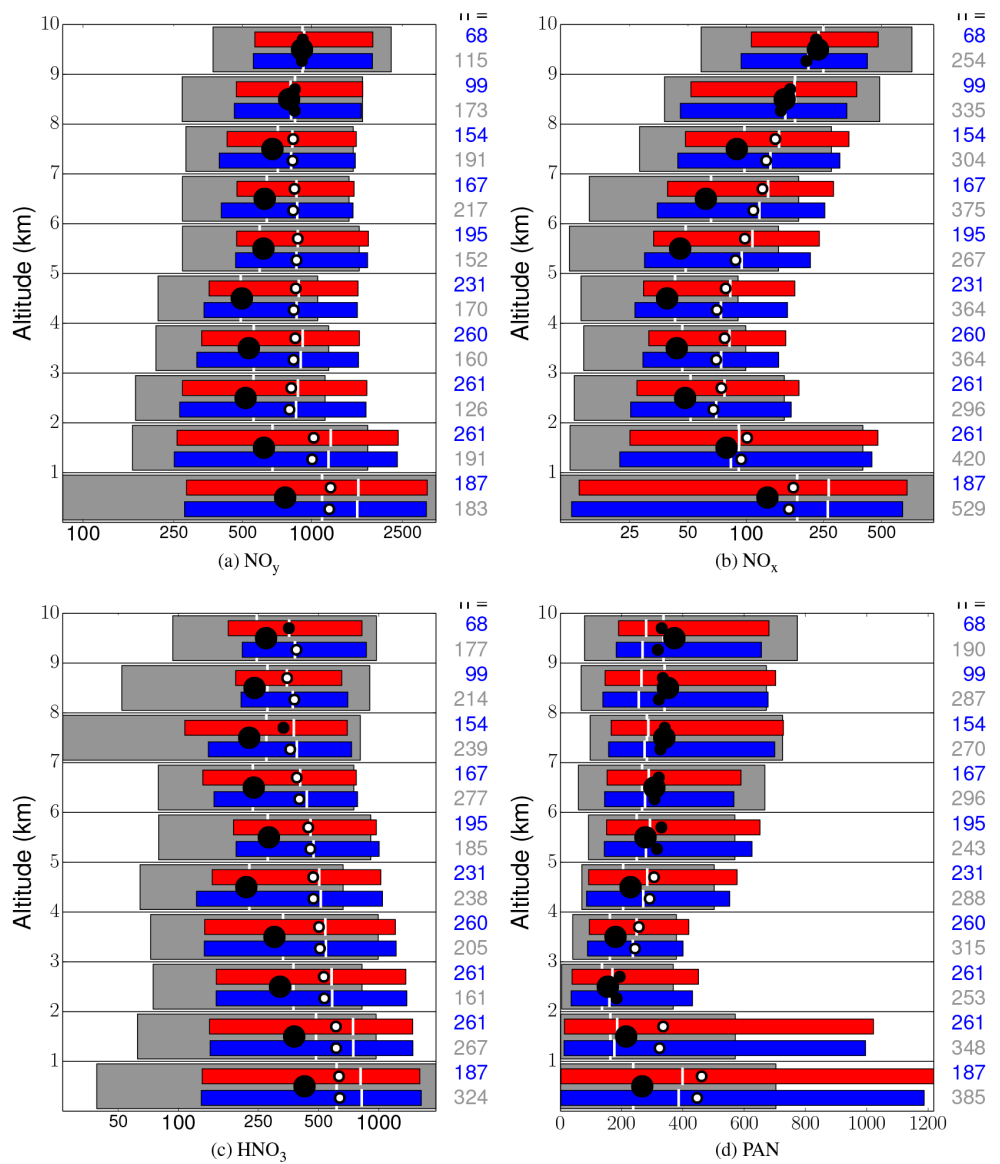

Figure A1. Same as Fig. 2 for concentrations instead of $\mathrm{NO}_{y}$ fractions. 


\section{The Supplement related to this article is available online at doi:10.5194/acp-15-5973-2015-supplement.}

Acknowledgements. Special thanks Rob Pinder and Farhan Akhtar, as well as Melody Avery, Bruce Anderson, John Barrick, Donald Blake, Ed Browell, Anthony Clarke, Ron C. Cohen, Glenn Diskin, Alan Fried, Brian Heikes, Greg Huey, Jim Podolske, Glen Sachse, Rick Shetter, Hanwant Singh, Robert Talbot, David Tan, Stephanie Vay, Rodney Weber, Paul Wennberg, William Brune, Daniel Jacob, James Crawford, and the rest of the INTEX-A team for the DC-8 observational data.

In addition, the authors would like to thank two anonymous reviewers whose valuable comments helped to substantially improve this manuscript.

Edited by: M. Ammann

\section{References}

Allen, D. J., Pickering, K. E., Pinder, R. W., Henderson, B. H., Appel, K. W., and Prados, A.: Impact of lightning-NO on eastern United States photochemistry during the summer of 2006 as determined using the CMAQ model, Atmos. Chem. Phys., 12, 1737-1758, doi:10.5194/acp-12-1737-2012, 2012.

Atkinson, R., Baulch, D. L., Cox, R. A., Crowley, J. N., Hampson, R. F., Hynes, R. G., Jenkin, M. E., Rossi, M. J., and Troe, J.: Evaluated kinetic and photochemical data for atmospheric chemistry: Volume $\mathrm{I}-$ gas phase reactions of $\mathrm{O}_{x}, \mathrm{HO}_{x}, \mathrm{NO}_{x}$ and $\mathrm{SO}_{x}$ species, Atmos. Chem. Phys., 4, 1461-1738, doi:10.5194/acp-41461-2004, 2004.

Bell, N., Koch, D., and Shindell, D. T.: Impacts of chemistryaerosol coupling on tropospheric ozone and sulfate simulations in a general circulation model, J. Geophys. Res., 110, doi:10.1029/2004JD005538, 2005.

Bertram, T. H., Perring, A. E., Wooldridge, P. J., Crounse, J. D., Kwan, A. J., Wennberg, P. O., Scheuer, E., Dibb, J., Avery, M., Sachse, G., Vay, S. A., Crawford, J. H., McNaughton, C. S., Clarke, A., Pickering, K. E., Fuelberg, H., Huey, G., Blake, D. R., Singh, H. B., Hall, S. R., Shetter, R. E., Fried, A., Heikes, B. G., and Cohen, R. C.: Direct Measurements of the Convective Recycling of the Upper Troposphere, Science, 315, 816-820, doi:10.1126/science.1134548, 2007.

Bey, I., Jacob, D. J., Yantosca, R. M., Logan, J. A., Field, B. D., Fiore, A. M., Li, Q., Liu, H. Y., Mickley, L. J., and Schultz, M. G.: Global modeling of tropospheric chemistry with assimilated meteorology: Model description and evaluation, J. Geophys. Res., 106, 023073-023096, doi:10.1029/2001JD000807, 2001.

Browne, E. C., Perring, A. E., Wooldridge, P. J., Apel, E., Hall, S. R., Huey, L. G., Mao, J., Spencer, K. M., Clair, J. M. St., Weinheimer, A. J., Wisthaler, A., and Cohen, R. C.: Global and regional effects of the photochemistry of $\mathrm{CH}_{3} \mathrm{O}_{2} \mathrm{NO}_{2}$ : evidence from ARCTAS, Atmos. Chem. Phys., 11, 4209-4219, doi:10.5194/acp-11-4209-2011, 2011.
Chameides, W. L., Fehsenfeld, F., Rodgers, M. O., Cardelino, C., Martinez, J., Parrish, D., Lonneman, W., Lawson, D. R., Rasmussen, R. A., Zimmerman, P., Greenberg, J., Mlddleton, P., and Wang, T.: Ozone precursor relationships in the ambient atmosphere, J. Geophys. Res., 97, 6037, doi:10.1029/91JD03014, 1992.

Chen, D., Wang, Y., McElroy, M. B., He, K., Yantosca, R. M., and Le Sager, P.: Regional CO pollution and export in China simulated by the high-resolution nested-grid GEOS-Chem model, Atmos. Chem. Phys., 9, 3825-3839, doi:10.5194/acp-9-3825-2009, 2009.

Conley, A. J., Lamarque, J.-F., Vitt, F., Collins, W. D., and Kiehl, J.: PORT, a CESM tool for the diagnosis of radiative forcing, Geosci. Model Dev., 6, 469-476, doi:10.5194/gmd-6-469-2013, 2013.

Dallmann, T. R. and Harley, R. A.: Evaluation of mobile source emission trends in the United States, J. Geophys. Res., 115, D14305, doi:10.1029/2010JD013862, 2010.

Donahue, N. M.: Atmospheric chemistry: The reaction that wouldn't quit, Nature Chem., 3, 98-99, doi:10.1038/nchem.941, 2011.

Fusco, A. C. and Logan, J.: Analysis of 1970-1995 trends in tropospheric ozone at Northern Hemisphere midlatitudes with the GEOS-CHEM model, J. Geophys. Res., 108, 4449, doi:10.1029/2002JD002742, 2003.

Guenther, A., Karl, T., Harley, P., Wiedinmyer, C., Palmer, P. I., and Geron, C.: Estimates of global terrestrial isoprene emissions using MEGAN (Model of Emissions of Gases and Aerosols from Nature), Atmos. Chem. Phys., 6, 3181-3210, doi:10.5194/acp-63181-2006, 2006.

Henderson, B. H., Pinder, R. W., Crooks, J., Cohen, R. C., Carlton, A. G., Pye, H. O. T., and Vizuete, W.: Combining Bayesian methods and aircraft observations to constrain the $\mathrm{HO}^{\circ}+\mathrm{NO}_{2}$ reaction rate, Atmos. Chem. Phys., 12, 653-667, doi:10.5194/acp12-653-2012, 2012.

Hudman, R. C., Jacob, D. J., Turquety, S., Leibensperger, E. M., Murray, L. T., Wu, S., Gilliland, A. B., Avery, M., Bertram, T. H., Brune, W., Cohen, R. C., Dibb, J. E., Flocke, F. M., Fried, A., Holloway, J., Neuman, J. A., Orville, R., Perring, A., Ren, X., Sachse, G. W., Singh, H. B., Swanson, A., and Wooldridge, P. J.: Surface and lightning sources of nitrogen oxides over the United States: Magnitudes, chemical evolution, and outflow, J. Geophys. Res., 112, D12S05, doi:10.1029/2006JD007912, 2007.

Jacob, D. J., Logan, J. A., Gardner, G. M., Yevich, R. M., Spivakovsky, C. M., Wofsy, S. C., Sillman, S., and Prather, M. J.: Factors regulating ozone over the United States and its export to the global atmosphere, J. Geophys. Res., 98, 14817, doi:10.1029/98JD01224, 1993.

Jacobson, M. Z.: Fundamentals of atmospheric modeling, Cambridge University Press, Cambridge, UK; New York, 2nd ed edn., 2005.

Jaeglé, L., Jacob, D. J., Brune, W. H., Tan, D., Faloona, I. C., Weinheimer, A. J., Ridley, B. A., Campos, T. L., and Sachse, G. W.: Sources of $\mathrm{HO}_{x}$ and production of ozone in the upper troposphere over the United States, Geophys. Res. Lett., 25, 17091712, doi:10.1029/98GL00041, 1998a.

Jaeglé, L., Jacob, D. J., Wang, Y., Weinheimer, A. J., Ridley, B. A., Campos, T. L., Sachse, G. W., and Hagen, D. E.: Sources and chemistry of $\mathrm{NO}_{x}$ in the upper troposphere 
over the United States, Geophys. Res. Lett., 25, 1705-1708, doi:10.1029/97GL03591, 1998b.

Jaeglé, L., Jaffe, D., Price, H., Weiss-Penzias, P., Palmer, P., Evans, M., Jacob, D., and Bey, I.: Sources and budgets for $\mathrm{CO}$ and $\mathrm{O}_{3}$ in the northeastern Pacific during the spring of 2001: Results from the PHOBEA-II Experiment, J. Geophys. Res., 108, 8802, doi:10.1029/2002JD003121, 2003.

Kopacz, M., Jacob, D. J., Fisher, J. A., Logan, J. A., Zhang, L., Megretskaia, I. A., Yantosca, R. M., Singh, K., Henze, D. K., Burrows, J. P., Buchwitz, M., Khlystova, I., McMillan, W. W., Gille, J. C., Edwards, D. P., Eldering, A., Thouret, V., and Nedelec, P.: Global estimates of $\mathrm{CO}$ sources with high resolution by adjoint inversion of multiple satellite datasets (MOPITT, AIRS, SCIAMACHY, TES), Atmos. Chem. Phys., 10, 855-876, doi:10.5194/acp-10-855-2010, 2010.

Kuhns, H., Green, M., and Etyemezian, V.: Big Bend Regional Aerosol and Visibility Observational (BRAVO) Study Emissions Inventory, Desert Research Institute, Las Vegas, NV, 2003.

Liao, H., Seinfeld, J. H., Adams, P. J., and Mickley, L. J.: Global radiative forcing of coupled tropospheric ozone and aerosols in a unified general circulation model, J. Geophys. Res., 109, D16207, doi:10.1029/2003JD004456, 2004.

McKeen, S. A., Hsie, E.-Y., and Liu, S. C.: A study of the dependence of rural ozone on ozone precursors in the eastern United States, J. Geophys. Res., 96, 15377, doi:10.1029/91JD01282, 1991.

Millet, D. B., Guenther, A., Siegel, D. A., Nelson, N. B., Singh, H. B., de Gouw, J. A., Warneke, C., Williams, J., Eerdekens, G., Sinha, V., Karl, T., Flocke, F., Apel, E., Riemer, D. D., Palmer, P. I., and Barkley, M.: Global atmospheric budget of acetaldehyde: 3-D model analysis and constraints from in-situ and satellite observations, Atmos. Chem. Phys., 10, 3405-3425, doi:10.5194/acp-10-3405-2010, 2010.

Mollner, A. K., Valluvadasan, S., Feng, L., Sprague, M. K., Okumura, M., Milligan, D. B., Bloss, W. J., Sander, S. P., Martien, P. T., Harley, R. A., McCoy, A. B., and Carter, W. P. L.: Rate of Gas Phase Association of Hydroxyl Radical and Nitrogen Dioxide, Science, 330, 646-649, doi:10.1126/science.1193030, 2010.

Olivier, J., Berdowski, J., Peters, J., Bakker, J., Visschedijk, A., and Bloos, J.: Applications of EDGAR emission database for global atmospheric research, RIVM report 773301001/NRP report 410 $200051,2002$.

Ott, L. E., Pickering, K. E., Stenchikov, G. L., Allen, D. J., DeCaria, A. J., Ridley, B., Lin, R.-F., Lang, S., and Tao, W.-K.: Production of lightning NOx and its vertical distribution calculated from three-dimensional cloud-scale chemical transport model simulations, J. Geophys. Res., 115, D04301, doi:10.1029/2009JD011880, 2010.

Parrish, D. D.: Critical evaluation of US on-road vehicle emission inventories, Atmos. Environ., 40, 2288-2300, doi:10.1016/j.atmosenv.2005.11.033, 2006.

Sander, S., Abbatt, J., Barker, J., Burkholder, J., Friedl, R., Golden, D., Huie, R., Kolb, C., Kurylo, M., Moortgat, G., Orkin, V., and Wine, P.: Chemical Kinetics and Photochemical Data for Use in Atmospheric Studies, Evaluation No. 17, JPL Publication 10-6, Jet Propulsion Laboratory, Pasadena, 2011

Schuirmann, D. J.: A comparison of the Two One-Sided Tests Procedure and the Power Approach for assessing the equivalence of average bioavailability, J. Pharmacokin. Biopharmaceut., 15, 657-680, doi:10.1007/BF01068419, 1987.

Seinfeld, J. H.: Urban Air Pollution: State of the Science, Science, 243, 745-752, doi:10.1126/science.243.4892.745, 1989.

Shindell, D., Kuylenstierna, J. C. I., Vignati, E., van Dingenen, R., Amann, M., Klimont, Z., Anenberg, S. C., Muller, N., Janssens-Maenhout, G., Raes, F., Schwartz, J., Faluvegi, G., Pozzoli, L., Kupiainen, K., Hoglund-Isaksson, L., Emberson, L., Streets, D., Ramanathan, V., Hicks, K., Oanh, N. T. K., Milly, G., Williams, M., Demkine, V., and Fowler, D.: Simultaneously Mitigating Near-Term Climate Change and Improving Human Health and Food Security, Science, 335, 183-189, doi:10.1126/science.1210026, 2012.

Sillman, S., Logan, J. A., and Wofsy, S. C.: The sensitivity of ozone to nitrogen oxides and hydrocarbons in regional ozone episodes, J. Geophys. Res., 95, 1837, doi:10.1029/JD095iD02p01837, 1990.

Singh, H. B., Salas, L., Herlth, D., Kolyer, R., Czech, E., Avery, M., Crawford, J. H., Pierce, R. B., Sachse, G. W., Blake, D. R., Cohen, R. C., Bertram, T. H., Perring, A., Wooldridge, P. J., Dibb, J., Huey, G., Hudman, R. C., Turquety, S., Emmons, L. K., Flocke, F., Tang, Y., Carmichael, G. R., and Horowitz, L. W.: Reactive nitrogen distribution and partitioning in the North American troposphere and lowermost stratosphere, J. Geophys. Res., 112, D12S04, doi:10.1029/2006JD007664, 2007.

Streets, D. G., Bond, T., Carmichael, G. R., Fernandes, S., Fu, Q., He, D., Kilmont, Z., Nelson, S., Tsai, N., Wang, M., Woo, J., and Yarber, K.: An inventory of gaseous and primary aerosol emissions in Asia in the year 2000, J. Geophys. Res., 108, 8809, doi:10.1029/2002JD003093, 2003.

Streets, D. G., Zhang, Q., Wang, L., He, K., Hao, J., Wu, Y., Tang, Y., and Carmichael, G. R.: Revisiting China's CO emissions after the Transport and Chemical Evolution over the Pacific (TRACE-P) mission: Synthesis of inventories, atmospheric modeling, and observations, J. Geophys. Res., 111, D14306, doi:10.1029/2006JD007118, 2006.

van der Werf, G. R., Randerson, J. T., Giglio, L., Collatz, G. J., Kasibhatla, P. S., and Arellano Jr., A. F.: Interannual variability in global biomass burning emissions from 1997 to 2004, Atmos. Chem. Phys., 6, 3423-3441, doi:10.5194/acp-6-3423-2006, 2006.

Vestreng, V. and Klein, H.: Emission data reported to UNECE/EMEP: Quality assurance and trend analysis \& Presentation of WebDab, MSC-W Status Rep. 2002, 2002.

Welch, B. L.: The Generalization of "Student's" problem when several different population variances are involved, Biometrika, 34, 28-35, doi:10.1093/biomet/34.1-2.28, 1947.

West, J. J., Fiore, A. M., Horowitz, L. W., and Mauzerall, D. L.: Global health benefits of mitigating ozone pollution with methane emission controls, Proc. Natl. Acad. Sci., 103, 39883993, doi:10.1073/pnas.0600201103, 2006.

West, J. J., Naik, V., Horowitz, L. W., and Fiore, A. M.: Effect of regional precursor emission controls on long-range ozone transport - Part 2: Steady-state changes in ozone air quality and impacts on human mortality, Atmos. Chem. Phys., 9, 6095-6107, doi:10.5194/acp-9-6095-2009, 2009. 